\title{
PODNOSZENIE KWALIFIKACJI ZAWODOWYCH PRZEZ PRACOWNIKÓW JAKO INWESTYCJA W KAPITAŁ LUDZKI
}

WSTĘP

Działalność pracodawców w warunkach gospodarki wolnorynkowej to nieustanna walka o utrzymanie przewagi konkurencyjnej. W gospodarce opartej na wiedzy, konieczność doskonalenia i nieustannego rozwoju, nabiera coraz większego znaczenia. Za potrzebą inwestowania w rozwój zawodowy pracowników przemawia także idea kształcenia ustawicznego oraz wspólnotowa strategia flexicurity. Współcześnie to zasoby niematerialne, czyli wiedza, umiejętności, doświadczenie, stanowią źródło przewagi konkurencyjnej przedsiębiorstw. Osiągać przewagę konkurencyjną na wybranych przez siebie rynkach oraz podbijać dotąd niezdobyte rynki mogą te przedsiębiorstwa, które potrafią, na bazie posiadanych zasobów i umiejętności, wykreować i dostarczyć produkty zaspokajające potrzeby nabywców, w lepszy i bardziej efektywny sposób niż konkurenci ${ }^{1}$. Patrząc na to zagadnienie z perspektywy prawa pracy można powiedzieć, że tylko pracodawcy, którzy potrafią motywować pracowników i rozwijać tkwiący w nich potencjał, są w stanie budować silną pozycję ekonomiczną na rynku, nie tracąc przy tym z pola widzenia potrzeby zapewnienia pracownikom godziwego wynagrodzenia oraz pracy w warunkach umożliwiających pełny rozwój kompetencji i umiejętności posiadanych przez pracownika. Kapitał ludzki rozumiany jest jako zespół kompetencji wszystkich zatrudnionych pracowników oraz połączenie ich indywidualnych postaw i wartości składających się na kulturę organizacyjną przedsiębiorstwa². Odzwierciedla tkwiącą w człowieku zdolność do uczenia się

* Studentka, Uniwersytet Łódzki.

1 W. Jarecki, M. Kunasz, E. Mazur-Wierzbicka, P. Zwiech, Gospodarowanie kapitałem Iudzkim, Economicus, Szczecin 2010, s. 36-37.

2 A. Rundo, Kapitał ludzki a innowacyjność przedsiębiorstw, CeDeWu, Warszawa 2013, s. 11. 
i ciągłego doskonalenia. W odróżnieniu od zasobów niematerialnych przedsiębiorstwa, kapitał ludzki jest rozwojowy³. Należy jednak zauważyć, że choć kapitał ludzki ma charakter twórczy, to jego wartość ulega stopniowej deprecjacji na skutek biologicznego starzenia się ludzi oraz nieustannie ewoluujących potrzeb pracodawców w zakresie wiedzy, umiejętności i postaw. Inwestycje w profilaktykę zdrowotną, poprawę jakości życia oraz w podnoszenie kwalifikacji zawodowych, mogą proces deprecjacji kapitału ludzkiego opóźniać bądź ograniczać ${ }^{\text {. W }}$ związku z tak istotną rolą podnoszenia kwalifikacji zawodowych w procesie budowania przewagi konkurencyjnej pracodawców i potrzebą dostrzeżenia w pracownikach nie tylko źródła tej przewagi, ale również godności osoby ludzkiej, należy przyjrzeć się bliżej regulacji dotyczącej tej problematyki.

\section{PODNOSZENIE KWALIFIKACJI ZAWODOWYCH W ŚWIETLE REGULACJI KODEKSU PRACY}

Obowiązek ułatwiania pracownikom podnoszenia kwalifikacji zawodowych został podniesiony do rangi podstawowych zasad prawa pracy w art. 17 k.p. ${ }^{5}$ oraz wymieniony wśród podstawowych obowiązków pracodawcy w art. 94 pkt. 6 k.p. W doktrynie i orzecznictwie podkreśla się jednak, że komentowany przepis nie ma charakteru roszczeniowego. Pracodawca ma ułatwiać pracownikom podnoszenie kwalifikacji zawodowych, nie ma natomiast obowiązku szkolenia pracowników ${ }^{6}$. Zasady prawa pracy, wyrażone zarówno w art. 16 k.p., jak i w art. 17 k.p., nie dają podstaw, aby żądać od pracodawcy określonego zachowania i wykraczają poza to, czego można oczekiwać od pracodawcy w warunkach gospodarki wolnorynkowej ${ }^{7}$. Obowiązek ułatwiania pracownikom podnoszenia kwalifikacji zawodowych nie oznacza, że pracownik ma możliwość domagania się od pracodawcy zorganizowania i przeprowadzenia określonego rodzaju szkolenia, np. komputerowego ${ }^{8}$. Jak jednak słusznie podkreśla się w literaturze, art. 17 k.p. zawiera adresowaną do pracodawców dyrektywę o charakterze postulatywnym, co najmniej nieprzeszkadzania dokształcającemu się pracownikowi, np. przez zlecanie pracy w godzinach nadliczbowych ${ }^{9}$. Ułatwianie pracownikom

3 W. Jarecki, M. Kunasz, E. Mazur-Wierzbicka, P. Zwiech, Gospodarowanie..., s. 38.

4 B. Buchelt, I. Kubica, G. Łukasiewicz, J. Purgał-Popiela, Gospodarowanie kapitałem Iudzkim, Uniwersytet Ekonomiczny w Krakowie, Kraków 2014, s. 14.

5 Ustawa z dnia 26 czerwca 1974 r. Kodeks Pracy; tekst jedn. Dz.U. z 2014 r., poz. 1502 ze zm.

6 D. Dörre-Nowak, Komentarz do art. 17 k.p., [w:] B. Wagner (red.), Kodeks pracy 2011. Komentarz, Lex, Gdańsk 2011, s. 81.

7 Z. Góral, O kodeksowym katalogu zasad indywidualnego prawa pracy, Wolters Kluwer SA, Warszawa 2011, s. 200.

8 Wyrok SN z 25 maja 2005 r., I PKN 657/99, Lex nr 44904.

9 W. Perdeus, Komentarz do art. 17 k.p., [W:] K.W. Baran, Kodeks pracy. Komentarz, Lex, Warszawa 2014, s. 114. 
podnoszenia kwalifikacji zawodowych leży bowiem także w interesie pracodawcy, który musi jednakże uwzględniać przy tym swoje możliwości ekonomiczne. Dlatego też, należy zgodzić się z poglądem, iż zasadę tą, można byłoby usunąć z kodeksu pracy, gdyż kwestia ułatwiania pracownikom podnoszenia kwalifikacji zawodowych powinna być przedmiotem swobodnie zawieranej pomiędzy stronami stosunku pracy umowy o podnoszenie kwalifikacji zawodowych, zaś partnerzy społeczni ową kwestię regulować mogliby w drodze rokowań zbiorowych ${ }^{10}$.

O tym, jak istotne dla rozwoju pracownika jest podnoszenie kwalifikacji zawodowych, przekonuje również treść art. 102 k.p., zgodnie z którym, do wykonywania pracy określonego rodzaju lub na określonym stanowisku niezbędne może być posiadanie przez pracownika szczególnych kwalifikacji. Ponadto, kwalifikacje zawodowe pełnią rolę jednego z kryteriów służącego ustaleniu przysługującego pracownikowi wynagrodzenia ${ }^{11}$. Jeśli chodzi o powiązanie pomiędzy możliwością wykonywania pracy określonego rodzaju lub na określonym stanowisku a kwalifikacjami zawodowymi pracownika, to są takie zawody, do wykonywania których wymagane jest, aby pracownik posiadał stosowne kwalifikacje, które wynikać mogą z poszczególnych pragmatyk zawodowych albo przepisów prawa administracyjnego ${ }^{12}$. Takie ograniczenia w podejmowaniu działalności zawodowej ze względu na posiadane kwalifikacje mogą być podyktowane przede wszystkim interesem publicznym. Są bowiem takie stanowiska, które wymagają od osób je piastujących posiadania pewnych szczególnych umiejętności i cech ze względu na to, iż są to zawody zaufania publicznego, np. sędzia, notariusz. W wypadkach, w których przepisy szczególne, nie regulują kwestii kwalifikacji wymaganych od pracownika do wykonywania pracy określonego rodzaju lub na określonym stanowisku, wymagania kwalifikacyjne mogą zostać ustalone w układach zbiorowych pracy, regulaminach pracy oraz w rozporządzeniach płacowych ${ }^{13}$.

Pojęcie podnoszenia kwalifikacji zawodowych nie zostało przez ustawodawcę dostatecznie sprecyzowane. Odwołując się do regulacji zawartej w art. $103^{1} \S 1$ k.p. możemy jedynie stwierdzić, iż przez podnoszenie kwalifikacji zawodowych rozumie się zdobywanie lub uzupełnianie wiedzy i umiejętności przez pracownika z inicjatywy pracodawcy albo za jego zgodą. Tak sformułowana definicja jest niewątpliwie bardzo ogólna i nie daje jednoznacznej odpowiedzi na pytanie, czy ustawodawca miał na myśli kwalifikacje niezbędne do wykonywania pracy u danego pracodawcy czy też chodzi o kwalifikacje w ogólności, niemające bezpośredniego związku z pracą zawodową ${ }^{14}$. Biorąc jednak pod uwagę, iż powoływany przepis nie przewiduje żadnych

10 Z. Góral, 0 kodeksowym..., s. 200.

11 J. Skoczyński, Komentarz do art. 102 k.p., [w:] L. Florek (red.), Kodeks pracy. Komentarz, Lex, Warszawa 2011, s. 556.

12 Ibidem, s. 556.

13 M. Raczkowski, Komentarz do art. 102 k.p., [w:] M. Gersdorf, K. Rączka, M. Raczkowski, Kodeks Pracy. Komentarz, Lex, Warszawa 2014, s. 725.

14 A. Dral, Podnoszenie kwalifikacji zawodowych przez pracowników z inicjatywy lub za zgodą pracodawcy, „Monitor Prawa Pracy” 2010, nr 11, s. 568. 
wyłączeń, a jego literalne brzmienie nie ogranicza zdobywania wiedzy i umiejętności jedynie do obszaru związanego z charakterem wykonywanej przez pracownika pracy, należy moim zdaniem zgodzić się z poglądem, iż zakres przedmiotowy definicji sformułowanej w art. $103^{1} \S 1$ k.p., obejmuje wszelkie formy, które mają na celu zdobywanie lub uzupełnianie wiedzy i umiejętności ${ }^{15}$. Stąd też w ramach podnoszenia kwalifikacji zawodowych przez pracowników, będą się mieściły formy szkolne, a więc nauka w szkołach wyższych, studia podyplomowe oraz formy pozaszkolne, typu szkolenia, prelekcje, kursy, konferencje, seminaria itp. Należy jednak pamiętać, że chociaż definicja podnoszenia kwalifikacji zawodowych obejmuje wszelkie formy pozyskiwania lub poszerzania zasobu wiedzy i umiejętności, to sformułowana w art. $103^{1} \S 1$ k.p. definicja podnoszenia kwalifikacji zawodowych zawiera w sobie element subiektywnej oceny pracodawcy, co do treści tego pojęcia i ten właśnie element subiektywny ma decydujące znaczenie dla określenia skutków prawnych związanych z dokształcaniem pracownika ${ }^{16}$. Zdobywanie lub uzupełnianie wiedzy i umiejętności przez pracownika można bowiem uznać za podnoszenie kwalifikacji zawodowych w rozumieniu kodeksowym tylko wtedy, gdy pracownik podejmuje działania w tym zakresie z inicjatywy pracodawcy, albo za jego zgodą. Bez tego nie jest możliwe takie stwierdzenie, bez względu na powiązanie podejmowanego przez pracownika szkolenia z zakresem aktualnie wykonywanych obowiązków pracowniczych.

\section{PRAWA I OBOWIAZZKI STRON STOSUNKU PRACY W ZWIAZZKU Z PODNOSZENIEM KWALIFIKACJI ZAWODOWYCH}

Konkretyzację powinności pracodawcy w związku z podnoszeniem kwalifikacji zawodowych zawierają przepisy art. $103^{1}-103^{6}$ k.p. Zakres tych obowiązków, jak również praw pracownika, zależy przede wszystkim od tego, czy pracodawca zawarł z pracownikiem podnoszącym kwalifikacje zawodowe, umowę, o której stanowi art. $103^{4}$ k.p. Zgodnie z art. $103^{1}$ k.p. podstawowymi uprawnieniami, które przysługują pracownikowi podnoszącemu kwalifikacje zawodowe są: urlop szkoleniowy oraz zwolnienie z całości lub części dnia pracy, na czas niezbędny, by punktualnie przybyć na obowiązkowe zajęcia oraz na czas ich trwania. Za czas urlopu szkoleniowego oraz za czas zwolnienia całości lub części dnia pracy pracownik zachowuje prawo do wynagrodzenia. Nie dotyczy to jednak sytuacji, w której pracownik zdobywa lub uzupełnia wiedzę i umiejętności na zasadach innych niż określone w art. $103^{1}-103^{5}$ k.p., czyli bez zgody bądź inicjatywy pracodawcy w tym zakresie. Takiemu pracownikowi mogą zostać przyznane, zgodnie z tym, co stanowi art. $103^{6}$ k.p., zwolnienie

15 Ibidem, s. 568; por. także: P. Wojciechowski, Podnoszenie kwalifikacji zawodowych pracowników po zmianach - zasady i wątpliwości, „Monitor Prawa Pracy” 2010, nr 11, s. 585.

16 J. Skoczyński, Komentarz do art. 1031, [w:] L. Florek (red.), Kodeks pracy..., s. 560. 
z całości lub części dnia pracy, ale bez zachowania prawa do wynagrodzenia oraz bezpłatny urlop szkoleniowy w ustalonym przez strony stosunku pracy wymiarze.

Wymiar urlopu szkoleniowego określony został przez ustawodawcę w art. $103^{2}$ k.p. i zgodnie z treścią tego przepisu, o czasie jego trwania przesądza rodzaj egzaminu, do którego przystępuje pracownik. Wymiar zwolnienia od pracy zależy zaś przede wszystkim od sytuacji konkretnego pracownika, tj. od jego programu zajęć i obowiązującego go rozkładu czasu pracy ${ }^{17}$. Pracownikowi nie przysługuje jednak zwolnienie od pracy, gdy program nauki w ramach podnoszenia kwalifikacji zawodowych przewiduje zajęcia wyłącznie w czasie wolnym pracownika ${ }^{18}$.

Obecnie pracownik może skorzystać z urlopu szkoleniowego w przypadku, gdy przystępuje do enumeratywnie określonej kategorii egzaminów kończących naukę oraz w związku z przygotowaniem pracy dyplomowej. Na gruncie poprzednio obowiązującego rozporządzenia Ministra Edukacji oraz Ministra Pracy i Polityki Socjalnej z dnia 12 października 1993 r. w sprawie zasad i warunków podnoszenia kwalifikacji zawodowych i wykształcenia ogólnego dorosłych ${ }^{19}$, istniały także urlopy szkoleniowe udzielane pracownikom w każdym roku studiów wyższych w celu przygotowania się i przystąpienia do egzaminów oraz w celu uczestnictwa w obowiązkowych zajęciach ${ }^{20}$.

Należałoby się zastanowić, czy właściwe było pominięcie w obecnym kształcie regulacji dotyczącej urlopów szkoleniowych tych urlopów, które przysługiwały niegdyś pracownikowi w każdym roku studiów wyższych w celu przygotowania się i przystąpienia do egzaminów. Byłoby to zresztą zgodne z ideą ułatwiania pracownikom podnoszenia kwalifikacji zawodowych. Aby pracownik mógł przygotować pracę dyplomową i następnie przystąpić do jej obrony musi zdać egzaminy, do których zaliczenia jest obowiązany zgodnie z obowiązującym dla danego kierunku programem studiów. Do osiągnięcia tego celu niezbędny jest natomiast nie tylko wysiłek intelektualny, ale również czas, który umożliwi pracownikowi naukę i wypoczynek konieczny dla wydajnej pracy. Dlatego też zawarty w art. $103^{2}$ k.p. katalog egzaminów, z którymi powiązane jest uprawnienie pracownika do skorzystania z urlopu szkoleniowego, jest niepełny i powinien zostać uzupełniony o urlopy udzielane pracownikowi w każdym roku studiów w celu przygotowania i przystąpienia do egzaminów.

Urlopu szkoleniowego udziela się w dni, które są dla pracownika dniami pracy, zgodnie z obowiązującym go rozkładem czasu pracy. Jeśli chodzi o termin, w którym pracownik powinien wystąpić z wnioskiem udzielenie urlopu, to nie jest to kwestia rozstrzygnięta jednoznacznie przez ustawodawcę. Dlatego też należy przyjąć, że osta-

17 M. Nałęcz, Komentarz do art. 1031 k.p., [w:] W. Muszalski, Kodeks pracy. Komentarz, Lex, Warszawa 2013, s. 293.

18 M. Frączek, O podnoszeniu kwalifikacji zawodowych w kodeksie pracy, „Służba Pracownicza" 2010, nr 11, s. 10.

19 Rozporządzenie Ministra Edukacji oraz Ministra Pracy i Polityki Socjalnej z dnia 12 października 1993 r. w sprawie zasad i warunków podnoszenia kwalifikacji zawodowych i wykształcenia ogólnego dorosłych, Dz.U. Nr 103, poz. 472 ze zm.

20 J. Skoczyński, Komentarz do art. 1032, [w:] L. Florek (red.), Kodeks..., s. 562. 
teczna decyzja w tym przedmiocie powinna należeć do pracodawcy, co jednak nie oznacza zupełnej dowolności. Należy zgodzić się z reprezentowanym w literaturze stanowiskiem, iż pracodawca powinien mieć na względzie przeznaczenie tej instytu$\mathrm{cji}^{21}$. Dni wolne od pracy powinny być udzielone w okresie bezpośrednio poprzedzającym przystąpienie przez pracownika do egzaminu, jeśli zaś chodzi o urlop udzielany pracownikowi studiującemu w rozumieniu przepisów ustawy Prawo o szkolnictwie wyższym, pracownik powinien mieć możliwość nie tylko przystąpienia do egzaminu, ale również przygotowanie pracy dyplomowej, a następnie przygotowanie się do egzaminu dyplomowego. Pracownik i pracodawca kwestię terminu, w ciągu którego zostanie wykorzystany urlop szkoleniowy, mogą też uregulować w drodze umownej. Urlop szkoleniowy może być wykorzystany w całości lub podzielony na części22.

Uprawnienia wymienione $w$ art. $103^{1} \S 1$ k.p. mają obligatoryjny charakter ${ }^{23}$. Dla ich uzyskania wystarczające jest, iż została spełniona przesłanka w postaci inicjatywy pracodawcy lub jego zgody na podnoszenie przez pracownika kwalifikacji zawodowych. Zgodnie z treścią art. $103^{4} \S 2$ k.p., umowa szkoleniowa nie może zawierać postanowień mniej korzystnych dla pracownika niż przepisy rozdziału III k.p. Uprawnienia, o których mowa, nie mogą zostać wyłączone na mocy umowy, ponieważ jej celem nie jest wyłączenie uprawnień przysługujących pracownikowi na mocy ustawy, a uzupełnienie ich podstawowej treści przy uwzględnieniu zasady działania na korzyść pracownika. Tak więc, nie można w drodze umowy szkoleniowej wyłączyć ani obniżyć standardów obowiązkowych świadczeń, jakie należą się pracownikowi od pracodawcy w związku z podnoszeniem kwalifikacji zawodowych, np. pracodawca nie może obniżyć wymiaru przysługującego pracownikowi urlopu szkoleniowego. To ograniczenie swobody stron w kształtowaniu treści umowy wynika zresztą nie tylko z przepisu art. $103^{4} \S 2$ k.p., ale również z ochronnego charakteru prawa pracy i funkcjonowania w ramach tej gałęzi prawa przepisów, które w przeważającej mierze są przepisami jednostronnie bezwzględnie obowiązującymi ${ }^{24}$.

Przedmiotem umowy szkoleniowej mogą być postanowienia odnoszące się do podstawowych świadczeń przewidzianych przez k.p. dla pracownika podnoszącego swoje kwalifikacje oraz postanowienia dotyczące świadczeń dodatkowych, o których stanowi art. $103^{3}$ k.p. Świadczeniami dodatkowymi na rzecz pracownika mogą być w szczególności: zobowiązanie pracodawcy do pokrycia opłat za kształcenie, przejazdy, podręczniki i zakwaterowanie. Nie jest to jednak katalog zamknięty. Przedmiotem umowy mogą być także ustalenia dotyczące okresu, w ciągu którego pracownik będzie zobowiązany do pozostawania w zatrudnieniu u danego pracodawcy po ukończeniu podnoszenia kwalifikacji zawodowych. Okres ten nie może być jednak dłuższy niż 3 lata.

21 M. Włodarczyk, Komentarz do art. 1032, [w:] K.W. Baran (red.), Kodeks..., s. 743.

22 M. Nałęcz, Komentarz do art. 1032, [w:] W. Muszalski (red.), Kodeks..., s. 295.

23 M. Raczkowski, Komentarz do art. 1031 k.p., [w:] M. Gersdorf, K. Rączka, M. Raczkowski, Kodeks Pracy. Komentarz, s. 730.

24 J. Skoczyński, Komentarz do art. 1034, [w:] L. Florek (red.), Kodeks..., s. 571. 


\section{OCHRONA INTERESU PRACODAWCY W ŚWIETLE PRZEPISÓW DOTYCZACYCH PODNOSZENIA KWALIFIKACJI ZAWODOWYCH}

Podstawę dla zawarcia umowy szkoleniowej stanowi art. $103^{4}$ k.p. Z brzmienia tego przepisu wynika, że pracodawca ma obowiązek zawarcia takiej umowy tylko w sytuacji, gdy zamierza zobowiązać pracownika do pozostawania w zatrudnieniu po ukończeniu podnoszenia kwalifikacji zawodowych. Wynika to z faktu, iż zobowiązanie pracownika na mocy umowy szkoleniowej do pozostania w stosunku pracy po zakończeniu podnoszenia kwalifikacji zawodowych jest postacią ograniczenia konstytucyjnej gwarantowanej zasady wolności pracy. To oczywiste, że pracownik po zakończeniu szkolenia, staje się bardziej konkurencyjny na rynku pracy. Dlatego może być zainteresowany rozwiązaniem dotychczasowej umowy o pracę i nawiązaniem nowego stosunku pracy na korzystniejszych warunkach. Natomiast, jeśli szkolenie, w którym uczestniczy pracownik ma bezpośredni związek z wykonywaną pracą, to niewątpliwie, w takiej sytuacji dochodzi także do przysporzenia po stronie pracodawcy. Jeśli więc można mówić jednocześnie o korzyściach jakie uzyskuje pracodawca w związku z dokształcaniem pracownika i ograniczeniu w podejmowaniu zatrudnienia przez pracownika, to stosownym jest ukształtowanie w drodze umowy wzajemnych praw i obowiązków w sposób, który ten układ korzyści i zobowiązań odzwierciedla.

Pracodawca, inwestując w szkolenia pracownicze, mające usprawnić aktualnie wykonywaną pracę na danym stanowisku, czyni to w tym celu, aby zatrzymać pracownika i wykorzystać powiększony w ten sposób kapitał ludzki. Jeśli pracodawca decyduje się przyznać pracownikowi podnoszącemu kwalifikacje zawodowe dodatkowe świadczenia, mimo iż nie musi tego czynić, to ma prawo oczekiwać, że poczynione na pracownika nakłady nie tylko się zwrócą, ale również znajdą przełożenie w wynikach pracy osiąganych przez pracownika w przyszłości. W związku z tym ważne jest, aby również ten aspekt podnoszenia kwalifikacji zawodowych został uwzględniony w umowie szkoleniowej.

Dla ochrony interesu pracodawcy istotny jest także przewidziany w art. $103^{5}$ k.p. obowiązek zwrotu kosztów poniesionych przez pracodawcę z tytułu dodatkowych świadczeń, udzielonych pracownikowi w umowie szkoleniowej w związku z dokształcaniem. Obowiązek, o którym stanowi art. $103^{5}$ k.p. obejmuje pracownika, który bez uzasadnionych przyczyn nie podejmie podnoszenia kwalifikacji zawodowych albo przerwie podnoszenie tych kwalifikacji, a także pracownika, z którym pracodawca rozwiąże stosunek pracy bez wypowiedzenia z jego winy w trakcie podnoszenia kwalifikacji zawodowych lub po jego ukończeniu w terminie określonym w umowie szkoleniowej, nie dłuższym jednak niż 3 lata, pracownika, który w okresie wskazanym w umowie szkoleniowej, nie dłuższym niż 3 lata, rozwiąże stosunek pracy za wypowiedzeniem, z wyjątkiem wypowiedzenia umowy o pracę z powodu mobbingu oraz 
pracownika, który w okresie wskazanym w umowie szkoleniowej nie dłuższym niż 3 lata, rozwiąże stosunek pracy bez wypowiedzenia na podstawie art. 55 lub $94^{3}$ k.p., mimo braku przyczyn określonych w tych przepisach. Art. $103^{5}$ k.p. stanowi jednak tylko o zwrocie świadczeń dodatkowych. Obowiązek zwrotu kosztów w sytuacji, gdy rezultat kształcenia nie zostanie osiągnięty z winy pracownika, nie obejmuje więc świadczeń obowiązkowych, co słusznie budzi wątpliwości w literaturze ${ }^{25}$. Nieuwzględnienie przez ustawodawcę tego aspektu ochrony interesu pracodawcy, może bowiem skutecznie zniechęcać pracodawców do inwestowania w rozwój zawodowy pracowników.

Chociaż zobowiązanie pracownika do pozostania w zatrudnieniu po ukończeniu podnoszenia kwalifikacji zawodowych, stanowi przejaw ograniczenia konstytucyjnie i ustawowo gwarantowanej zasady wolności pracy, to jednak ma swoje uzasadnienie właśnie w konieczności uwzględnienia nakładów, jakie wiążą się dla pracodawcy z dokształcaniem pracownika. Nie można bowiem dopuścić do sytuacji, w której pracownik budowałby swoją pozycję na rynku pracy kosztem pracodawcy, tym bardziej, że każda forma dokształcania stanowi w pewnym zakresie korzyść także dla samego pracownika, niezależnie od tego, czy szkolenie jest bezpośrednio związane z wykonywaną przez pracownika pracą zawodową, czy też ma charakter ogólnorozwojowy. Pracodawca powinien mieć możliwość wykorzystania pozyskanego lub poszerzonego zasobu wiedzy i umiejętności pracownika w pewien czas po zakończeniu podnoszenia kwalifikacji zawodowych. Zwłaszcza w odniesieniu do pracowników wykonujących zawody uznawane na rynku pracy za deficytowe bądź posiadających wysoce specjalistyczną wiedzę, dotyczącą np. zastosowania nowoczesnych technologii w procesie produkcji, niebezpieczeństwo „ucieczki” pracownika wzrasta. Obawy związane z przewidywanym brakiem czasu na spożytkowanie efektów kształcenia pracownika, stanowią zaś jedną z przyczyn braku inwestycji w kształcenie dorosłych $^{26}$. To zresztą nie jedyne powody braku dostatecznych nakładów na podnoszenie kwalifikacji zawodowych przez pracowników. Polscy pracodawcy wskazują także na brak dostatecznych zasobów finansowych przedsiębiorstwa, brak stabilizacji na rynku, konieczność zmniejszenia biurokracji oraz podwyższenia jakości oferty szkoleniowej. Pracodawcy nie są też często świadomi korzyści, jakie może im przynieść inwestowanie w kształcenie pracowników. Zdarza się także, że problem tkwi w samych pracownikach, którzy z różnych powodów nie mogą lub nie chcą podnosić swych kompetencji zawodowych ${ }^{27}$. W przeprowadzonym w kwietniu 2011 r. badaniu „Ustawiczne kształcenie w przedsiębiorstwach”, pracodawcy wskazywali także, że obecne kwalifikacje i umiejętności zatrudnionych odpowiadają w pełni potrzebom przedsiębiorstwa, oraz że przedsiębiorstwa prowadzą strategię zatrudniania osób o odpowiednim poziomie kwalifikacji ${ }^{28}$.

25 A. Dral, Podnoszenie..., s. 571.

26 E. Strojna, Szkolenia - to się opłaca, „Służba Pracownicza” 2010, nr 11, s. 5.

27 Ibidem, s, 6.

28 www.stat.gov.pl/obszary-tematyczne/edukacja/edukacja/ksztalcenie-zawodowe-wprzedsiebiorstwach-w-polsce-w-2010-r-,4,2.html [dostęp: 10.11.2014]. 


\section{PODSUMOWANIE}

Reasumując, podnoszenie kwalifikacji zawodowych przez pracowników to inwestycja, która przynosi korzyści zarówno dla pracownika, jak i pracodawcy. Obecnie, w dobie globalizacji, postępu naukowo-technicznego i otwarcia granic w związku z przystąpieniem Polski do UE, sytuacja na rynku pracy podlega bardzo szybkim zmianom, za którymi pracownik powinien nadążać, aby móc zwiększyć swoje szanse na zdobycie i utrzymanie satysfakcjonującej i godziwie wynagradzanej pracy. Analizując tendencje, jakie możemy zaobserwować na współczesnym rynku pracy nie sposób nie zwrócić także uwagi na problem, który dotyka większość państw Europy Zachodniej, mianowicie starzenie się społeczeństw i w związku z tym możliwość pojawienia się w przyszłości niedoboru odpowiednio wykwalifikowanej kadry pracowniczej. Aby temu zaradzić konieczne jest stworzenie racjonalnej polityki mającej na celu aktywizację zawodową ludzi starszych ${ }^{29}$. Zmiany demograficzne, które już zostały zapoczątkowane przyniosą ze sobą nieodwracalne dla całego społeczeństwa skutki, wyznaczając tym samym kierunek pożądanych celów polityki rynku pracy. W związku z tym, gotowość pracowników do podnoszenia kwalifikacji zawodowych, niezależnie od wieku, powinna odpowiadać otwartości pracodawców na inicjatywę pracowników w tym zakresie. Zdobywanie, uzupełnianie wiedzy i umiejętności przez pracowników to inwestycja, która przynosi korzyści zarówno dla pracownika, pracodawców, jak i całego społeczeństwa.

\section{BIBLIOGRAFIA}

Baran K.W. (red.), Kodeks pracy. Komentarz, Lex, Warszawa 2014.

Buchelt B., Kubica I., Łukasiewicz G., Purgał-Popiela J., Gospodarowanie kapitałem Iudzkim, Uniwersytet Ekonomiczny w Krakowie, Kraków 2014.

Dral A., Podnoszenie kwalifikacji zawodowych przez pracowników z inicjatywy lub za zgodą pracodawcy, „Monitor Prawa Pracy” 2010, nr 11.

Florek L. (red.), Kodeks pracy. Komentarz, Wolters Kluwer SA, Warszawa 2011.

Frączek M., O podnoszeniu kwalifikacji zawodowych w kodeksie pracy, „Służba Pracownicza” 2010, nr 11.

Frączkowski K., Zarządzanie projektem informatycznym, Oficyna Wydawnicza Politechniki Wrocławskiej, Wrocław 2003.

Gersdorf M., Rączka K., Raczkowski M., Kodeks Pracy. Komentarz, Lex, Warszawa 2014.

Góral Z., O kodeksowym katalogu zasad indywidualnego prawa pracy, Wolters Kluwer SA, Warszawa 2011.

Jarecki W., Kunasz M., Mazur-Wierzbicka E., Zwiech P., Gospodarowanie kapitałem ludzkim, Economicus, Szczecin 2010.

Muszalski W. (red.), Kodeks pracy. Komentarz, Lex, Warszawa 2013.

29 J. Liwiński, U. Sztanderska, Zarządzanie wiekiem w przedsiębiorstwie, www.parp.gov.pl/ files/74/87/110/10073.pdf [dostęp: 10.11.2014]. 
Rundo A., Kapitał ludzki a innowacyjność przedsiębiorstw, CeDeWu, Warszawa 2013.

Strojna E., Szkolenia - to się opłaca, „Służba Pracownicza” 2010, nr 11.

Wagner B. (red.), Kodeks Pracy 2011. Komentarz, Gdańsk 2011.

Wojciechowski P., Podnoszenie kwalifikacji zawodowych pracowników po zmianach - zasady i wątpliwości, „Monitor Prawa Pracy” 2010, nr 11.

\section{Źródła internetowe}

http://stat.gov.pl/obszary-tematyczne/edukacja/edukacja/ksztalcenie-zawodowe-w-przedsiebiorstwach-w-polsce-w-2010-r-,4,2.html

http://www.parp.gov.pl/files/74/517/19001.pdf

\section{Akty prawne}

Rozporządzenie Ministra Edukacji oraz Ministra Pracy i Polityki Socjalnej z dnia 12 października 1993 r. w sprawie zasad i warunków podnoszenia kwalifikacji zawodowych i wykształcenia ogólnego dorosłych, Dz.U. Nr 103, poz. 472 z późn. zm.

Ustawa z dnia 26 czerwca 1974 r. - Kodeks Pracy; tekst jedn. Dz.U. z 2014 r., poz. 1502 z późn. zm.

Wyrok SN z 25 maja 2005 r., I PKN 657/99, Lex nr 44904. 